\title{
Acquiring possessives
}

Book or Report Section

Accepted Version

Marinis, T. (2016) Acquiring possessives. In: Lidz, J., Snyder, W. and Pater, J. (eds.) Oxford Handbook of Developmental Linguistics. Oxford University Press, Oxford, pp. 435-462. ISBN 9780199601264 doi:

https://doi.org/10.1093/oxfordhb/9780199601264.013.19 Available at http://centaur.reading.ac.uk/52377/

It is advisable to refer to the publisher's version if you intend to cite from the work. See Guidance on citing.

To link to this article DOI:

http://dx.doi.org/10.1093/oxfordhb/9780199601264.013.19

Publisher: Oxford University Press

All outputs in CentAUR are protected by Intellectual Property Rights law, including copyright law. Copyright and IPR is retained by the creators or other copyright holders. Terms and conditions for use of this material are defined in the End User Agreement. 


\section{www.reading.ac.uk/centaur}

\section{CentAUR}

Central Archive at the University of Reading

Reading's research outputs online 
Acquiring Possessives

Theodoros Marinis

School of Psychology \& Clinical Language Sciences

University of Reading

\section{Address for correspondence:}

Theodoros Marinis

School of Psychology \& Clinical Language Sciences

University of Reading

Reading RG6 6AL

UK

Tel. +44-118-378 7465

e-mail: t.marinis@reading.ac.uk 


\section{Introduction}

The concepts of possession and ownership are amongst the first concepts expressed by children when they start acquiring language. Ownership and possession can be expressed in different ways, for example through adnominal possession, as illustrated in (1), predicative possession, as shown in (2), and external possession, as in (3) below (for detailed cross-linguistic discussion on possessives from a theoretical perspective, see Baron, Herslund, \& Sørensen, 2001).
(1) Adnominal possession
(a) Mummy's hat
(b) My sister's cat
(c) The cat of my sister

(2) Predicative possession

(a) Mummy has a hat.

(b) This hat belongs to mummy

(c) This hat is mine.

(3) External possession

(a) He pinched Mary on the cheek.

In adnominal possession, possessor and possessum are part of the same noun phrase, whereas in predicative possession they are arguments of a predicate, like have, belong, and be. In external possession, they are also arguments of a predicate, but the lexical meaning of the predicate does 
not have the notion of possession, as shown in (3a). With the exception of Eisenbeiß, Matsuo \& Sonnenstuhl (2009), the vast majority of acquisition studies have investigated the acquisition of adnominal possession. Therefore, this chapter will focus only on this type of possession and with the way it is acquired in children with typical language development. In the next section I will provide an overview of the properties of adnominal possession in a variety of languages (English, German, Greek, Hebrew, and Japanese) and consider some learnability issues. Then I will review literature on the acquisition of adnominal possession in those five languages. The final section will discuss the acquisition literature in relation to the learnability issues and will identify some avenues for future research on the acquisition of possessives.

\section{Adnominal possession across languages}

As with many other phenomena, there is cross-linguistic variation in the way adnominal possession is expressed across languages. Some languages, like English, German, and Greek have two types of adnominal possession, non-prepositional and prepositional possessives, whereas other languages, like Hebrew, have only prepositional possessives. Examples (4) and (5) illustrate non-prepositional and prepositional possessives in English, German, and Greek. Nonprepositional possessives involve genitive case, as shown in (4a) to (4f).

(4) Non-prepositional possessives

(a) Peter's house (English)

(b) Daddy's bike (English)

(c) Peters/Marias Haus (German)

'Peter's/Maria's house' 
(d) Papas/Mamas Rad (German)

'daddy's/mummy's bike'

(e) Die Mutter der Schüllerin (German)

the mother the-gen Student-gen

'the mother of the student'

(f) I mitera tis mathitrias (Greek)

the mother the-gen student-gen

'the mother of the student.'

(g) TIS MATHITRIAS $^{1}$ i mitera (Greek)

the-gen student-gen the mother

'the mother of the student.'

There are also cross-linguistic differences in the word order used in the possessive construction. English has the word order possessor-possessum, as shown in (4a) and (4b), whereas German and Greek allow two word orders: possessor-possessum and possessum-possessor, as shown in (4c) to (4g). Cross-linguistic variation is also attested in the way possessives are encoded in terms of inflectional morphology. In English, possessives are marked with the suffix $-s$ on the possessor, as shown in (4a) and (4b). In German, the word order possessor-possessum is marked with the possessive marker $-s$, as shown in (4c) to (4d), whereas the word order possessumpossessor is marked with genitive case, as shown in (4e). The difference is apparent with feminine nouns that are used with the possessive $-s$ in the possessor-possessum word order (4c-

\footnotetext{
${ }^{1}$ Capitals represent focalisation.
} 
4d), but with the genitive case in the possessum-possessor order (4e). Similarly to German, Greek has two possible word orders (possessor-possessum and possessum-possessor); genitive case is used in the same way in both word orders, but the word order possessor-possessum involves focalisation, which is indicated in the examples with capital letters.

Prepositional possessives involve the prepositions of (English), von (German), apo (Greek), as shown in (5a) to (5c) and English allows also the use of the possessive $-s$ with the prepositional possessive, as shown in (5d).

(5) Prepositional possessives

(a) a chapter of this book (English)

(b) ein Kapitel von diesem Buch (German) a chapter of this book 'A chapter of this book.'

(c) ena kefaleo apo afto to vivlio (Greek) a chapter of this the book 'A chapter of this book.'

(d) a friend of John's

In all three languages, the possessor can be expressed with a pronoun when it can be identified from the discourse, as shown in (6) for non-prepositional possessives and in (7) for prepositional possessives. 
(6)Non-prepositional possessive

(a) John loves his house (English)

(b) Jochen liebt sein Haus (German)

'John loves his house'

(c) $\mathrm{O}$ Giannis aghapai to spiti tu (Greek)

the John loves the house his-gen

'John loves his house'

(7)Prepositional possessive

(a) Bill and a friend of his came to the party. (English)

(b) Bill und ein Freund von ihm kam zu der Party. (German)

'Bill and a friend of his came to the party'

(c) To trito rafi apo afti ti ntulapa ke to deftero apo

the third shelf of this the wardrobe and the second of

ekini ine leromena. (Greek)

that are dirty

'The third shelf of this wardrobe and the second one of that one are dirty.'

Another interesting property of possessives is their ability to form recursive possessives with the possessive $-s$ in English, as in (8a) and (8b) (Roeper, 2007), with genitive in Greek, as in (8c), or with prepositional possessives, as in (8d).

(8a) John's friend's car (from Roeper, 2007: 112)

(8b) My mother's friend's daughter (from Roeper, 2007: 112) 
(8c) I kori tis filis tis miteras mu the daughter the-gen friend-gen the-gen mummy-gen my 'My mother's friend's daughter.'

(8d) A daughter of a friend of my mother

Recursive possessives are language specific. For example, they are grammatical in English and Greek, but not in German.

In terms of the syntactic representation of possessives, since Abney (1987) and the Determiner Phrase (DP) hypothesis, Noun Phrases (NPs) are analysed as projections of the functional category Determiner (D). According to this analysis, in English non-prepositional possessives the possessor occupies the head of the DP, as shown in (9) below.

(9)

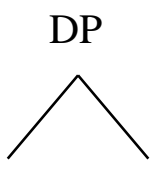

Peter D'

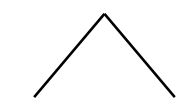

D

-s

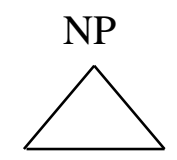

house 
According to a more recent analysis within the minimalist programme, an optional functional category hosts possessors (Adger, 2003) ${ }^{2}$, as shown in (10) below.

(10)

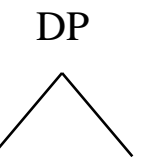

Possessor D'

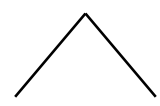

$\mathrm{D}$

\section{PossP}

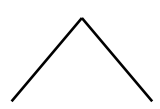

(Possessor) Poss'

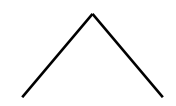

Poss

$n \mathrm{P}$

In this analysis, possessors are merged in the specifier of the PossP and then move to the specifier of the DP. The role of the functional head Poss is to introduce a semantic relationship between the possessor and the $n \mathrm{P}$, a possessor argument at a lower level of the representation. In addition, the availability of more than one structural positions within the DP allows for crosslinguistic variation of the position of possessors (Adger, 2003)

In terms of the distribution of prepositional vs. non-prepositional possessives, nonprepositional possessives in English are preferred when expressing prototypical and inalienable

\footnotetext{
${ }^{2}$ See also Alexiadou (2001) for the distinction between inalienable and alienable possession. According to Alexiadou, alienable possession involves only a DP, whereas inalienable possession involves also a PossP.
} 
possessive relationships (e.g., John's hair), when the possessor is animate, topical, and light, whereas prepositional possessives are preferred with inanimate, non-topical, and heavy (syntactically modified) possessors (e.g., the sound of the car's exhaust).

In German, there is a syntactic constraint for the use of non-prepositional possessives with the possessive suffix $-s$. This suffix can be used only with nominals that lack articles and other modifiers (e.g. adjectives), such as proper names (4c) and kinship terms (4d) (Eisenbeiß et al., 2009).

In German it is possible to move the prepositional possessive to the left of the possessum for emphasis, as shown in (11) below.

Das ist bestimmt VON PAUL der Freund (from Eisenbeiß, et al. 2009)
this is surely of Paul the friend
'This is surely Paul's friend.'

This is the case also in Greek, i.e., it is possible to move the possessor to the left of the possessum for emphatic reasons, as shown in (12) below.

Zestana TU MORU to ghala
heated the-gen baby-gen the milk
'I heated the milk of the baby.


Finally, some spoken German dialects, such as Bernese Swiss German, have a dative possessive construction that involves a possessor in the dative case and a resumptive possessive pronoun, as shown in (13).

Dem Vater sein Hut

(from Penner \& Weissenborn, 1994)

the-dat father his hat

'Father's hat.'

The dative possessive construction involves a dative marked possessor, the possessum, and an expletive possessive pronoun that agrees with the possessor and the possessum in gender and number. According to Penner \& Weissenborn (1996), the dative possessive structure involves movement of the possessor to the Specifier of the DP.

Hebrew has only one type of adnominal possessives, prepositional possessives (the Free Genitive construction), as shown in (14).

$$
\begin{aligned}
& \text { xeder shel ima } \\
& \text { room of mummy } \\
& \text { 'Mummy's room.' }
\end{aligned}
$$

(from Armon-Lotem 1998)

This involves the case marker shel $(=$ of $)$. According to standard analyses of the Free Genitive in Hebrew, such as Ritter (1991), Borer (1999), and Siloni (1996), the base order is possessorpossessum, which is ungrammatical in adult Hebrew. The possessor is base-generated in Spec,NP. The order possessum-possessor is the result of N-movement of the possessum to the 
specifier of the DP (see Borer 1994 as cited by Armon-Lotem 1998) or to the specifier of a functional projection between the DP and the NP, i.e. to Spec,AgrP according to Siloni (1996), and to Spec,NumP according to Ritter (1991).

Finally, in the Japanese possessive construction, the possessor precedes the possessum and the possessor is marked with the genitive particle no (Eisenbeiß et al. 2009), as shown in (15).

(15) Toshiko no kuruma (from Eisenbeiß et al. 2009)

'Toshiko's car'

To summarise this section, all human languages express the notion of possession and in the languages presented, adnominal possession involves the structure of the DP. However, there is considerable cross-linguistic variation in the way adnominal possession is grammaticalized across languages. The variation regards:

1. whether the language has prepositional and/or non-prepositional possessives and their distribution;

2. in the case of prepositional possessives, which lexical items (prepositions) are used in prepositional possessives;

3. in the case of non-prepositional possessives, how is possessive/genitive case expressed, i.e. which morphemes encode genitive case, what word-order possibilities are available, and what conditions determine a specific word order.

4. whether the language has pronominal possessives, which lexical items are used in pronominal possessives and their distribution; 
5. whether the language allows recursive possessives.

Children have to deduce the correct grammatical options for their target language from the input they encounter. From a learnability perspective, this raises several questions:

1. How do phonological, prosodic and general constraints on utterance length affect the children's use of possessives?

2. What is the role of general purpose learning principles, like rote-learning and distributional analysis?

3. What is the role of frequency?

4. Do children use base word orders earlier than derived word orders?

The next section will review studies on the acquisition of adnominal possessives in English, German, Greek, Hebrew, and Japanese.

\section{Acquisition of the possessive construction}

Studies on the acquisition of the possessive construction from the 60s and the 70s followed mainly a descriptive approach. This changed in the 80 s and the 90 s when studies within the generative framework focused on the acquisition of possessives with the aim to show whether or not the DP is present in the children's early grammar. 


\subsection{Acquisition of possessives in English}

Research on the acquisition of possessives in English from the 60s onwards has demonstrated that at an early stage of development, children omit the possessive suffix $-s$ in non-prepositional possessives, as shown in (16); in prepositional possessives, they omit the preposition of, as shown in (17) to (18) below (Bloom, 1970; Bowerman, 1973; Brown \& Bellugi, 1964; de Villiers \& de Villiers, 1973; Radford, 1990; Tomasello, 1998).

(16) Mommy milk; Lauren house (Travis, 17 months) (from Tomasello, 1998: 354)

(17) Picture Gia (Gia 20 months) (from Radford, 1990: 91)

(18) Picture Kendall; Picture water (Kendall 23 months) (from Radford, 1990: 92)

Some studies have shown that while children omit the genitive possessive $-s$ in possessorpossessum utterances, they do use it when they use only the possessor in isolation, as shown in (19) and (20) below.

(19) Mommy’s. Mommy key (Gia 20 months) (from Bloom, 1970: 93)

(20) That Daddy’s; That Kimmy ball (Kendall 23 months) (from Bowerman, 1973: 242)

In the diary study of his daughter, Tomasello (1998) also provides information about the duration of genitive possessive omission. The first use of the non-prepositional possessive was at the age of 1;5 in possessor-possessum constructions with the genitive possessive $-s$ omitted. This period lasted for 10 days and was followed by a period of variable use of $-s$ that lasted for another 10 days, after which Travis used $-s$ consistently. In the next few weeks, Travis started using the 
possessive-possessum construction with $-s$ also in utterances including a verb, as shown in (21) below.

(21) Cat bit Daddy’s finger (Travis 1;6.7) (from Tomasello, 1998: 358)

Pronominal possessives emerged at the age of $1 ; 6.27$, i.e. after the genitive possessive $-s$ was used consistently. The first occurrence of pronominal possessives consisted of the pronoun mine, as shown in (22), and after about a week Travis used my for the first time, as shown in (23). In this period, mine and my were used interchangeably, as shown in (24) and (25) until the age of 1;9, after which there was consistent use of mine and my.

(22) Mine pillow (Travis 1;6;27) (from Tomasello, 1998: 359)

(23) My book; my water; my hose. (Travis 1;7.8) (from Tomasello, 1998: 359)

(24) Drink mine tea (Travis 1;8;19) (from Tomasello, 1998: 366)

(25) Brush my teeth (Travis 1;8.13) (from Tomasello, 1998: 366)

Another case study on the acquisition of possessives in English was reported in Radford \& Galasso (1998). In this study, the child (Nicholas) did not use possessive $-s$ in any of the 118 contexts between the age of $2 ; 3$ and $3 ; 1$, and between the age of $3 ; 2$ to $3 ; 6$ he used only $23 \%$ of $-s$ in 14 out of 60 contexts. However, during the time when Nicholas was not using any possessive $-s$, he did use pronominal possessives. This is in contrast to the study by Tomasello showing that pronominal possessives emerged after Travis used possessive $-s$ consistently. In 
Radford \& Galasso's study, between 2;6 and 2;8 pronominal possessives were predominantly in the accusative case $\left(96 \%\right.$, in 53 out 55 contexts), as shown in (26). ${ }^{3}$

(26) That me car; Have me show; Where me car. (from Radford \& Galasso 1998: 40)

From 2;9 and until 2;11, the rate of pronominal possessives in genitive case increased and fluctuated between $56 \%$ and $79 \%$ and at the age of $3 ; 0$ it exceeded $90 \%$.

The acquisition of recursive possessives has been discussed in Roeper (2007) and Roeper \& Snyder (2005) based on naturalistic data from a range of studies. Roeper (2007) reported that Sarah (Brown, 1973) from the age of three to the age of five had difficulties with recursion and another child translated double possessives, such as 'The Dukes of Hazzard's boy's car' into a single possessive and a compound, i.e. 'The boy's Dukes of Hazzard car' (Roeper, 2007: 116). According to Roeper, children use the possessive $-s$ first as a marker of concord, as shown in (27), and only later in embedded recursion structures, as shown in (28) (Armstrong, 2001).

(27) He's Fred Flintstone's Fred's friend (from Armstrong, 2001, cited in Roeper, 2007: 117) (28) What's Toto's girl's name? (from Armstrong, 2001, cited in Roeper, 2007: 117)

Two more recent studies used experimental designs to test the comprehension (Limbach \& Adone, 2010) and production (Pérez-Leroux, Castilla-Earls, Bejar, \& Massam, in press) of recursive possessives in English children. Limbach \& Adone tested the comprehension of

\footnotetext{
${ }^{3}$ It should be noted that Nicholas was growing up in England, where some dialects allow 'me' for 'my'.
} 
recursive possessives using stories with toys. Children heard a story, saw the experimenter acting out the story and then had to answer to a comprehension question by selecting a picture. The study included 3-, 4-, and 5-year-old children, a control group of adults and a group of adult second language learners of English. The children were less accurate than the adults (61\% vs. $83 \%$ ), but they performed above chance. There was no difference between the three age groups of children in terms of their accuracy (3-year-olds: 56\%; 4-year-olds: 70\%, 5-year-olds: 59\%), but they did not show the same error pattern. The most frequent error type in 3-year old children was disregarding the middle possessive, i.e. they were interpreting John's brother's car as John's car. This is similar to the observation by Roeper, mentioned above. The most frequent error in 5-year-olds was using a conjunctive reading, i.e. they were interpreting the same sentence as John and his father's car. Finally, the most frequent error type in the adult data was making an error related to the first name, e.g. for the same sentence choosing Jane's father's car. These data show that young children have difficulties in the interpretation of recursive possessives and follow different strategies as they pass through developmental stages.

Pérez-Leroux, Castilla-Earls, Bejar, \& Massam (in press) tested also 3- to 5-year-old children, but they used an elicitation task with stories to elicit recursive possessives, along with PP modifiers (The baby with the woman with the flowers), and sentences involving coordination (An Elmo, a bicycle and a doll). Recursive possessives and PP modifiers both involve embedding. The results showed that adults responded using mainly recursive structures, whereas children used predominantly non-recursive structures. Children had more difficulties to produce structures with embedding than structures without embedding and there was a significant difference between 3- and 4-year-olds vs. 5-year-olds. In addition, children had more difficulties to produce recursive possessives than PP modifiers and there was only one single recursive 
possessive response in the children data (out of 138 contexts). The group of adults elicited 7 recursive possessive (out of 33 contexts). These data provide further evidence that although simple possessives (John's car) are early acquired, recursive possessives (John's father's car) are acquired late.

To summarise the data on the acquisition of adnominal possessives in English, at the initial stage, children omit the genitive possessive $-s$ and the preposition $o f$. This is followed by a stage of variable use, which is followed by a stage of consistent use. Some studies have observed consistent use of $-s$ when the child is using only the possessor. In terms of possessive pronouns, at an earlier stage, children do not use them in the genitive case, but in the accusative case and they substitute my with mine. In addition, there seems to be individual variation in the emergence of possessive pronouns. Some children start using possessive pronouns before the use of possessive $-s$, whereas others start using possessive pronouns after consistent use of $-s$. Finally, recursive possessives are acquired late.

Radford (1990) has taken the omission of $-s$ and of as evidence to argue that children at an early stage of development pass through a lexical stage, in which they have not acquired the functional category D, and are thus, not projecting DPs. To explain the use of $-s$ when the possessor is used without the possessum, Radford suggested that $-s$ in these cases is an impostor, i.e. it has a different status than in the adult system. A slightly different analysis was proposed in Radford \& Galasso (1998). According to this analysis, variable use of possessive $-s$ and genitive marked possessive pronouns provide evidence for underspecification of functional categories. 


\subsection{Acquisition of possessives in German}

Research on the acquisition of possessives in German has revealed to a certain extent similarities to the pattern of development of possessives in English, but also differences relating to crosslinguistic variation.

The similarities regard the acquisition of the possessive morpheme $-s$. Eisenbeiß (2000) and Eisenbeiß, Matsuo \& Sonnenstuhl (2009) analysed the data of seven children between the ages of 1;11 and 3;6 and Penner \& Weissenborn (1996) analysed the Simone Corpus and diary data from Juwal, a child acquiring Bernese German.

Eisenbeiß (2000) identified three stages in the acquisition of the possessive marker $-s$. At the first stage, the possessive marker $-s$ is absent. This stage was attested in the speech of three children, Annelie, Leonie, and Matthias, as shown in (29) below.

(29) SE: Und Papas Hose brauchen wir noch. (Leonie, 2;1) (from Eisenbeiß 2000) and daddy's pants need we still

Leonie: da papa hose there daddy pants

The children's age and MLU in words for Annelie was 2;5-2;7 (MLU: 2.1-2.6), for Leonie 1;112;1 (MLU: 1.57-1.67), and for Mathias 2;4-2;5 (MLU: 1.46-1.75).

The next stage was characterised by variable use of the possessive $-s$, as shown in (30) and (31) below.

(30) hm papas gürtel (Andreas 2;1) (from Eisenbeiß 2000) 
'Hm dady's belt'

(31) e mama ticktack is(t) das (Andreas 2;1) (from Eisenbeiß 2000)

e mummy watch is that

'This is mummy's watch.'

This stage was identified in two children, Leonie and Andreas. The children's age and MLU in words at this stage was 2;2-2;4 (MLU: 1.6-2.08) for Leonie and 2;1 (MLU: 2.44) for Andreas. These stages do not seem to correspond to specific age and MLU ranges. For example, Annelie at the first stage was older and had larger MLU than Leonie at the second stage. At this stage, possessive $-s$ was used with a specific set of nouns that were frequent in the input and the possessor always preceded the possessum. This reflects the target word-order when there are no determiners preceding the nouns.

In the third stage, children used the possessive $-s$ consistently. This was attested in four children: Hannah (age: 2;4-2;6; MLU: 1.65-2.45), Leonie (age: 2;5-2;11; MLU: 1.86-3.06), Mathias (age: 3;1-3;6; MLU: 2.24-3.51), and Svenja (age: 2;9-3;03; MLU: 3.47-3.99).

Interestingly, in the data of two children, Leonie and Svenja, the possessive $-s$ was not restricted only to proper names and kinship terms, that is, it did not follow the language specific constraints for German, but it was also used with other animate nouns, as shown in (32) and (33) below. This is ungrammatical in the target language.

(32) $\mathrm{SE}^{4}:$ Das is?

\footnotetext{
${ }^{4} \mathrm{SE}=$ Sonja Eisenbeiß
} 
'This is?'

Leonie: affes banana (Leonie 2;4)

'Monkey’s banana.' (from Eisenbeiß 2000)

(33) SE: Und das is?

'And that is?'

Svenja: das is junges gürtel (Svenja 3;02)

'This is the boy's belt.' (from Eisenbeiß 2000)

Finally, Eisebeiß identified one utterance in the speech of Svenja and one in the speech of Simone, in which the word-order is possessum - possessor, as shown in (34) and (35) below.

(34) SE: für den Sascha?

for the Sascha

'For Sascha?'

Svenja: mhm die sascha die saschas ziehn wer erstmal an ${ }^{5}$ (Svenja 3;02)

Mhm the Sascha the Sascha's (shoes) put we first on

'Mhm we will first put Sascha's shoes on.' (from Eisenbeiß 2000)

(35) SE: Sag mal, was is'n das, Mensch?

'Tell me what is this, man?'

Simone: mones das sind die fisch mones. (Simone 2;4)

mones these are the fish mones

\footnotetext{
${ }^{5}$ But note that here the noun is missing in this example; the word order is hypothesised based on the use of the article.
} 
'These are Mone’s fish.' (from Eisenbeiß 2000)

These utterances appear after Svenja and Simone have started using the possessive $-S$ consistently.

Eisenbeiß et al. (2009) also analysed the acquisition of possessive pronouns, prepositional possessives, and genitive constructions with the order possessum-possessor in the same dataset. Their analyses showed that possessive pronouns emerge later than possessive $-s$ with proper names and kinship terms, but as the children get older, the proportion of pronominal possessives increases. In addition, pronominal possessives were initially restricted to the form 'mein'=my and were either uninflected or incorrectly inflected. Thus, there was no evidence for target-like agreement.

Prepositional possessives emerged much later than pronominal possessives, and genitive constructions with the order possessum-possessor were the latest to emerge in their dataset.

Finally, Eisenbeiß et al. (2009) looked at whether or not the children were sensitive to two constraints on the use of adnominal possessives: 1) a semantic constraint, according to which the possessive $-s$ can only be used with proper names and kinship terms and not with common nouns, and 2) prohibition of using possessive $-s$ with modified possessors. The children in their dataset violated the first constraint, that is, they overgeneralised $-s$ with common nouns. This error type was also reported in Mills (1985):185), e.g. das ist Männers Wagen (= that is the men's car). However, children did not violate the second constraint. The difference between the two constraints is that the first one is a lexical one, whereas the second one is a syntactic one. Children violated the lexical constraint, but not the syntactical one. 
Eisenbeiß (2000) took the omission of the possessive $-s$ to show that the DP is not operative in the early stages. Variability in the use of $-s$ was taken to reflect underspecification of the DP and use of $-s$ with a specific set of nouns was taken to support the Lexical Learning Hypothesis, according to which $-s$ is initially stored individually for each possessor noun and only later is it generalized to new nouns. The data on word-order, i.e. the use of the word-order possessorpossessum from the very beginning, even when the possessive marker $-s$ was omitted, could be used as evidence for the availability of SpecDP because many analyses of the German DP assume that the possessor is base generated as a complement of $\mathrm{N}$ and moves to SpecDP. However, there are also analyses, according to which the possessor is generated to the left of the possessum, in which case the order possessor-possessum does not provide evidence for movement and availability of the DP. Eisenbeiß supports the latter analysis and argues for base generation of the word-order possessor-possessum.

Penner \& Weissenborn (1996) investigated the acquisition of the possessive construction in Standard German based on the longitudinal data of Simone from 1;09.11 to 2;07.04, the child analysed also in Eisenbeiß, and Bernese Swiss German on diary data of one child, Juwal, between the ages of $1 ; 2$ and $2 ; 8$.

The pattern attested in Simone's speech was similar with the pattern attested in Eisenbeiß (2000). Initially Simone used possessor-possessum structures without the genitive possessive $-S$, but there was an isolated example of a possessor with $-s$ that was used without the possessum, as shown in (36). From the age of 2;0.23 there was variable use of $-s$ and after the age of 2;04.17 there was consistent use of $-s$.

(36) Mones (Simone 1;11.13) (from Penner \& Weissenborn, 1996) 


\section{'Simone's'}

In terms of the acquisition of the dative possessive construction, Penner \& Weissenborn mentioned only three instances of this construction in Simone's speech. ${ }^{6}$ All had dative case marking on the possessor, but in the first two that were attested at the age of $2 ; 0$ and $2 ; 1$, the possessive pronoun was omitted, as shown in (37). The possessive pronoun was attested only at the age of 2;11, as shown in (38).

(37) der Mone Balla is weg (Simone 2;01.12)

the-dat Simone ball is gone

'Simone’s ball is gone.' (from Penner \& Weissenborn, 1996)

(38) der Jan is Nina ihr Bruder (Simone 2;11.18)

the-dat Jan is Nina ihr Bruder

'Jan is Nina's brother' (from Penner \& Weissenborn, 1996)

Mills (1985: 187) also mentioned examples of this construction from the Stern data (Stern \& Stern, 1907), e.g. is'n de Hilde ihr Stülchen (2;6) (= it's Hilde's chair).

In Bernese Swiss German, Penner \& Weissenborn identified three stages in the acquisition of the dative possessive construction in the speech of Juwal. In the first stage there are two utterances that involve the possessive construction with the order possessor-possessum, but without dative case and the possessive pronoun, as shown (39) below.

\footnotetext{
${ }^{6}$ It is not clear if the dative possessive construction was part of Simone's input.
} 
(39) Nomi Bett (Juwal 1;06.14)

Naomi bed

'Naomi’s bed' (from Penner \& Weissenborn, 1996)

At the second stage, there were 18 utterances involving the possessive construction. Six of those were similar to the utterances in Stage 1, but there were 11 utterances involving the possessive construction that consisted of the possessor followed by the possessive pronoun, but without dative case and without the possessum, as shown in (40) and (41). The possessive pronoun in these examples was used in the unmarked neuter singular form, i.e. there was no evidence for agreement with the possessor and there were also instances of lack of person agreement, as shown in (41). Finally, there was an instance of the word order possessum-possessor, as shown in (42).

(40) Mami sis (Juwal 1;07.29)

mommy its-neut-sg

'Mommy’s' (from Penner \& Weissenborn, 1996)

(41) Nomi mis (Juwal 1;07.02)

Naomi mine-1sg-neut-sg

'Naomi's' (points to Naomi’s alarm clock) (from Penner \& Weissenborn, 1996)

(42) (J)agge (Ju)wal (Juwal 1;07.01)

Jacket Juwal

'The jacket of Juwal' (from Penner \& Weissenborn, 1996) 
At the third stage, there were 71 instances of the dative possessive. Some instances were similar to Stages 1 and 2, but there were also instances of the possessive construction involving for the first time both the possessive and the possessum and the possessive pronoun, as shown in (43).

(43) Nadaw sis Ue (Juwal 1;10.19)

Nadaw-neut-sg watch-fem-sg

'Nadaw's watch' (from Penner \& Weissenborn, 1996)

The possessive pronoun was still used in the unmarked form, i.e. there were no gender and number distinctions and it did not agree with the possessor or the possessum and there was no dative case marking. At the age of 2;03.14, Penner \& Weissenborn observed the first instance of the possessive construction with dative marking, as shown in (44) below, and from 2;03.14 to 2;05.01 only 4 out of the 16 instances were marked with dative case.

(44) am Juwal sine

to-the-dat Juwal his-masc-sg

'Juwal's' (from Penner \& Weissenborn, 1996)

Based on these data, Penner \& Weissenborn argued that case marking is acquired after the emergence of the functional category $\mathrm{D}$ and movement of the possessor to the specifier of the DP. 
To summarise, the data on the acquisition of adnominal possessives in German and Swiss German, similarly to English at the initial stage children omit the genitive possessive $-s$. This is followed by a stage of variable use of $-s$. At this stage, there is lexically restricted use of the possessive $-s$ only with a specific set of nouns that are frequent in the input. This stage is followed by consistent use of $-s$. These three stages were attested in several children, but did not correspond to specific ages or MLU stages. Possessive pronouns seemed to emerge later than possessive $-s$ but with age, possessive pronouns became more frequent than possessive $-s$.

In terms of the word order, the order possessor-possessum, which according to Eisenbeiß is the base word order, emerged prior to the word order possessum-possessor in possessorpossessum utterances requiring $-s$ and also in dative possessive constructions. This was the case even when children omitted possessive $-s$ and did not use the dative possessive pronoun or when they used a possessive pronoun in the unmarked form. There were very few instances of the possessive construction with the order possessum-possessor.

Finally, as far as lexical and syntactic constraints are concerned, all children were sensitive to the syntactic constraint that disallows the use of the possessive $-s$ with modified nouns, but two children were not sensitive to the semantic constraint, according to which $-s$ can only be used with proper names and kinship terms.

\subsection{Acquisition of possessives in Greek}

The acquisition of possessives in Greek has been investigated by Stephany (1995) and Marinis (2000, 2002, 2003); Christofidou (1998) investigated the acquisition of case marking. Stephany's study is based on the Stephany Corpus that includes data from five children (Janna, Mairi, Maria, Spiros, and Jana) (MacWhinney \& Snow, 1990). Christofidou analysed data from 
one child (Christos) (Christofidou Corpus). Marinis (2002, 2003) analysed data from all children of the Stephany and the Christofidou Corpus.

Since Greek has two possible word orders, possessum-possessor (the unmarked order) and possessor-possessum that involves focalisation, one of the key questions was to find out whether the unmarked word-order emerges before the one involving focalisation. A second languagespecific property of Greek is that the possessor has to be marked for genitive case on the determiner and the noun. The determiner and the noun agree in gender, number, and case.

Marinis showed that the first instances of the possessive construction in Greek consisted of isolated possessors. This was attested in the speech of three children, Christos, Janna, and Mairi, as shown below.

i Mairis ine. (Mairi 1;9.25)

the-nom Mairis-gen are

'They belong to Mairi.' (from Marinis 2003)

(46) ine nanula. (Janna $1 ; 11)$

is Anula-nom/acc

'It's Anula's.' (from Marinis 2003)

This stage was followed by the use of the possessor and possessum in the unmarked order (possessum-possessor), as shown below. This order was attested in the speech of all five children.

Adult: afto ti ine? 
this what is

'What is this?'

Child: lululi mamach. (Christos $1 ; 11.19)$

flower mummy-gen

'Mummy's flower.' (from Marinis 2003)

(48) Child: tha pai ti thesi ti ghatas. (Mairi 2;3)

fut-prt ${ }^{7}$ go the position the-un ${ }^{8}$ cat-gen

'It will go the position of the cat.'

Adult: to papaki den beni sti thesi tis ghatas.

the duck-dim ${ }^{9}$ not go to-the position the-gen cat

'The small duck doesn't fit to the position of the cat.'

At the next stage, children used both word orders, possessum-possessor and possessor-

possessum. This was attested in the speech of three children, Christos, Maria, and Mairi. The following examples illustrate the word-order possessor-possessum.

(49) Adult: ke pu kimate?

and where sleeps

'And where is he sleeping?'

Child: ti ghiaghias to kevati. (Mairi 2;9.15)

\footnotetext{
${ }^{7}$ fut-prt $=$ future particle

${ }^{8}$ un $=$ unmarked for case

${ }^{9} \operatorname{dim}=$ diminutive
} 
the-un grandma-gen the bed

'In grandma's bed.'

(50) Child: iko

Bebe. (Christos 2;0.7)

Niku-un BMW

'Niko's BMW.'

Adult: $\mathrm{i}$ Beemve tu thiu Niku ine afti?
the BMW the uncle Niku is this

'Is this uncle Nikos' BMW?'

For the acquisition of genitive case, Christofidou (1998) showed that in the Christofidou Corpus genitive case on the noun emerged at the age of 1;11.19 and was used contrastively with the nominative/accusative form, as shown in (47) above. However, initially it was used only with one noun, i.e. mama (= mummy). Interestingly, this was the recording when the child was using the complete possessive construction possessum-possessor for the first time (Marinis, 2002). In fact, Marinis (2002) showed that genitive case on the possessor emerged at the same time with the word-order possessum-possessor in four (Christos, Spiros, Maria, Mairi) out of the five children analysed in that study. In the fifth child (Jana), genitive marking on the possessor noun emerged before the order possessum-possessor. However, the picture was different in the acquisition of genitive case on the definite article. At the time when children used genitive in the noun possessor, many definite articles were omitted and the ones present were used in the unmarked form, i.e. they were not used in the genitive case and there was no article-noun agreement. In the Christofidou Corpus, genitive marking on the definite article emerged when both word-orders were attested, but even then, it was not consistently marked (Marinis 2000; 
2003). Consistent use of genitive case on the definite article of the possessor was present only at the age of $2 ; 6$ and when the child reached $90 \%$ use of definite articles in obligatory contexts.

To summarise the data on the possessive construction in Greek, similarly to English and German, the first instances of the possessive construction attested were possessors in isolation. These were followed by the full possessive construction in the unmarked word order, i.e. possessum-possessor. At the final stage, children used both word orders. Genitive marking also showed similarities with English and German. Genitive case was initially lexically restricted. Interestingly, genitive case was initially marked on nouns and not on definite articles. This was at the stage when there was a high rate of definite article omission and the definite articles used were in the unmarked form. Genitive case marking was acquired relatively late, which is in line with the acquisition of genitive case in German.

\subsection{Acquisition of possessives in Hebrew}

The acquisition of the free genitive possessive construction in Hebrew was discussed briefly in Berman (1985), whereas more in depth studies looking at the developmental path of this construction were presented in Berman (1987) and Armon-Lotem (1998).

The Hebrew free genitive possessive displays one word order, i.e. possessum-possessor, as shown in example (51), and the possessor is preceded by the case marker shel (= of). The word order possessor-possessum is ungrammatical in Hebrew.

(51) xeder shel ima room of mommy 'Mommy's room.' (from Armon-Lotem 1998) 
According to Berman (1987), the free genitive possessive construction is acquired at 2;4-3;0. However, Berman (1985: 308) mentions that children mix the order of possessor and possessum, and sometimes say e.g. ha yeled shel ha kova (= the boy of the hat) to mean the boy's hat. In terms of the acquisition of shel, Berman (1985) mentions that they start using it initially with pronouns, as shown in (52) before they use it with nouns, as in (53).

buba shel-i

doll of-me

'My doll' (from Berman 1985:325)

(53) bayit shel Ron

house of Ron

'Ron's house' (from Berman 1985:325)

Armon-Lotem addressed the question of whether or not children use the target word order from the outset and also whether or not they use the case marking preposition shel. Based on the data from four children, Armon-Lotem suggested a three-stage developmental path: 1) possessorpossessum (unattested word order in the target language), 2) possessum-possessor (target wordorder), and 3) shel insertion.

This developmental path was attested in the data of two out of the four children she analysed (Leor and Smadar). These children did not initially use the target like word order, but they used the word order that is ungrammatical in the target language (possessor-possessum), as shown in (54). 
(54) $\quad$ ze Miryam sefer (Smadar, 1;06.19)

this Miriam book

'This (is) Miriam’s book' (from Armon-Lotem, 1998)

(55) sefer Miryam (Smadar, 1;07.07)

book Miriam

'Miriam's book' (from Armon-Lotem, 1998)

(56) Arik shel Miriami (Smadar, 1;10.19)

Arik of Miriam

'Miriam’s Arik (Ernie)' (from Armon-Lotem, 1998)

Leor used the target word order after about two weeks and Smadar after one month, as shown in (55). The case marker shel was acquired later on, as shown in (56). The remaining children did not pass through a stage of using the ungrammatical word order. Interestingly, when Leor and Smadar used the order possessor-possessum the case marker shel was missing. However, shel was also missing when they started using the target word order. Therefore, there is no evidence of a correlation between using shel and the target word order.

To summarise the findings on the acquisition of the possessive construction in Hebrew, similarly to the English data, children initially omit the preposition in prepositional possessives. In addition, some children use the base word order (possessor-possessum). However, the base word order is not a licit word order in the target language. As a result, these children seem to pass through a stage in which they use a word order that is not available in the target grammar. 


\subsection{Acquisition of possessives in Japanese}

Clancy (1985) reported data on the acquisition of Japanese from Okubo (1967), Miyahara (1974), and Komura (1981). Komura analysed data from two children and found two slightly different developmental patterns. One child expressed possession first only with the possessor and without the use of no. At a second stage, the child used no only with the possessor, as shown in (58) below.

(58) Noriko-chan no

'It's Noriko’s' (from Miyahara 1974, cited in Clancy 1985: 458)

At a third stage, the child used the possessor and the possessum, but no was omitted, as shown below and only later did the full construction emerge.

(59) neechan tokei

'Older sister's watch'

The second child did not show the first and the third stage, i.e. there was no evidence of using possessor without no, but the use of no with the possessive was variable at the very beginning. There was also no evidence of the use of possessor-possessum without no. When the child started using utterances with the possessor and the possessum, she used them with the case marker no.

Clancy suggested that these two developmental paths correspond to different speeds of acquisition, i.e. the child showing four different developmental stages corresponding to a slower, 
more typical course of development, and the child with only two stages of development corresponding to a rapid pace of development.

Interestingly, the stage of possessor-possessum with omission of no was attested also in one child from the sample analysed by Clancy. An example is given below. Clancy reports that no was omitted even when the child repeated this construction immediately after the target spoken by an adult.

neechan buubuu

older sister car

‘Older sister’s car’ (from Clancy 1985: 458)

Clancy reported that this child used no productively at the age of $2 ; 2-2 ; 4$ and from then onwards there were no instances of omission anymore.

To summarise the acquisition of the possessive construction in Japanese, similarly to the data from all languages presented earlier, children acquiring Japanese initially use the possessor in isolation and omit the particle no. The particle is used first with the possessor in isolation and only later in the full possessive construction.

\section{Discussion}

We will now consider the questions raised in Section 2 against the data from the five languages presented in Section 3 and then finish this paper by identifying some avenues for future research on the acquisition of possessives. 
As mentioned in Section 1, there is substantial cross-linguistic variation in the way adnominal possession is grammaticalized across languages. The cross-linguistic variation regards the availability of prepositional, non-prepositional, pronominal, and recursive possessives, the lexical items and word order used and their distribution. Based on the input, children have to find out how possession is grammaticalized in the language they acquire. This leads to the following questions. Of course this is not an exhaustive list.

1. How do phonological, prosodic and general constraints on utterance length affect the children's use of possessives?

2. What is the role of general purpose learning principles, like rote-learning and distributional analysis?

3. What is the role of frequency?

4. Do children use base word orders earlier than derived word orders?

Table 1 summarizes the main findings of the studies presented in Section 3.

Table 1: Summary of main findings in the five languages

\begin{tabular}{|c|c|c|c|c|c|}
\hline & 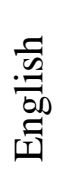 & 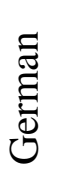 & 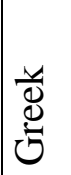 & $\mid \begin{array}{l}3 \\
0 \\
0 \\
0 \\
0 \\
0 \\
\end{array}$ & 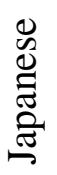 \\
\hline Omission of grammatical morphemes & + & + & + & + & + \\
\hline Lexical use of grammatical morphemes & + & + & + & $?$ & $?$ \\
\hline Variable use of grammatical morphemes & + & + & + & $?$ & + \\
\hline
\end{tabular}


Base prior to derived word-order

\begin{tabular}{|l|l|l|l|l|} 
N/A & + & + & + & N/A \\
\hline
\end{tabular}

$\mathrm{N} / \mathrm{A}=$ not applicable

$?=$ indicates a lack of relevant data in the language

\section{Omission of grammatical morphemes due to phonological, prosodic or length constraints}

In the data of all languages presented in Section 3, at a very early stage of development there is evidence of omission of bound and free grammatical morphemes expressing possession. For example, children acquiring English omit the possessive morpheme $-s$ and the preposition of and children acquiring Greek omit the genitive morpheme. Total lack of grammatical morphemes encoding possession could be caused by phonological constraints; for example, avoid codas (see Optimality Theory, Prince \& Smolensky, 2004). This hypothesis is relevant for the omission of possessive $-s$ in English and German and for the omission of genitive $-s$ in Greek. If the lack of these morphemes is due to phonological constraints, this would predict that children would also omit final $-s$ also in monomorphemic words.

This hypothesis could account for the omission of bound morphemes with specific phonological properties (final consonant), but could not account for the omission of prepositions, e.g. of in English and shel in Hebrew. The omission of prepositions could relate to prosodic constraints, for example, omit unstressed syllables (see Gerken, 1996). This hypothesis predicts that children would also omit other unstressed syllables, including unstressed syllables that are not grammatical morphemes. These two hypotheses need to be investigated in future research by comparing the acquisition of phonology and prosody to the acquisition of morpho-syntax.

A further hypothesis could be that children omit grammatical morphemes due to constraints on utterance length. At the one-word stage, children may express possession through the use of 
the noun expressing possession (e.g., Mommy) and at the two-word stage through the use of the possessor and the possessum (e.g., Mommy key) because of general limitations on the length of utterances and not because they have not analyzed the properties of the grammatical morphemes expressing possession. This hypothesis predicts that with increasing MLU, children would start using grammatical morphemes. Furthermore, the use of grammatical morphemes would depend on the length of the utterance and would not be consistent. For example, if there is a constraint of two morphemes per utterance, children would either use an utterance consisting of the possessor and the possessum (e.g., Mommy key) or the possessor with the possessive $-s$ (e.g., Mommy's). Such a stage has been identified in data on the acquisition of English (Bloom, 1970; Bowerman, 1973) and Greek (Marinis, 2003) possessives. Of course, a relevant issue that needs to be addressed is whether the grammatical morphemes used in early utterances have been analyzed by the children and are used productively or whether they represent unanalyzed wholes. In other words, is $-s$ in Mommy's a grammatical morpheme or is the child using it as one lexical item? To address this issue it is important to look at the distribution of possessives.

\section{Analyzing the input and frequency effects}

There is evidence from data on English, German, and Greek that children start using possessive morphemes initially with a limited number of nouns. This indicates lexical use of grammatical morphemes; children may be using Mommy vs. Mommy's contrastively but Mommy's may be an unanalyzed lexical item expressing possession. Such a developmental stage has been identified also for other grammatical morphemes (see, Tomasello, 2003) and seems to represent rotelearning and the pre-cursor of distributional analysis of the input. This stage is followed by a stage of variable use of grammatical morphemes marking possession including bound (suffixes) 
and free (prepositions) morphemes. This stage has been attested in English, German, Greek, and Japanese.

From a learnability perspective, we can assume that the concept of possession is universal and does not have to be acquired. What needs to be acquired are the means that express possession in each language: the availability of prepositional, non-prepositional, pronominal, and recursive possessives, the lexical items used in each language, their distribution, and the word order.

Possessives constructions are in general frequent in the children's input. Therefore, we can assume that general purpose learning mechanisms (Tomasello, 2003), such as distributional analyses, and probabilistic learning (Young, 2002) can be used by children to identify the grammatical morphemes that express possession, for example, through the use of minimal pairs. This applies for possessive $-s$ in English and German, genitive case in Greek, pronominal and prepositional possessives. Children can use general purpose learning principles to segment them from the input, map their features, and store them in the mental lexicon. These learning mechanisms can account for the variable use of these grammatical morphemes and their gradual development. What are the predictions for infrequent structures, such as recursive possessives?

Recursive possessives are infrequent in the input and are also syntactically more complex than non-recursive possessives. This predicts that they will be later acquired than non-recursive possessives. The data available for the acquisition of recursive possessives support this hypothesis. Three- to five-year-old children misinterpret and very rarely use recursive possessives.

\section{Base vs. derived word orders - frequency vs. syntactic structure}


Data on the acquisition of the possessive construction in German, Greek, and Hebrew have revealed that some children use initially the base word order and later the derived word order. In German and Greek, both word orders are available in the language. This means that the input to the child includes both word orders. The emergence of the base word order prior to the derived word order in German and Greek could result from: frequency, lack of syntactic structure, or it could be a sampling error. The derived word order is used for emphatic reasons and should, therefore, be less frequent than the base word order. Children may start using the word order that is more frequent in the input. In terms of the syntactic structure, the derived word order involves movement; children may not be using the derived word order because they have not acquired the movement apparatus and the requirements on movement. Another possibility is that the datasets analyzed in these studies did not include relevant contexts for the emphatic use of the possessive construction, and this is why the derived word order was not attested in the sample.

In contrast to German and Greek, Hebrew allows only the derived word order; the base word order is ungrammatical, and therefore, it is not part of the children's input. If the input is the only factor determining the pattern of language acquisition, children acquiring Hebrew should only use the derived word order and should never use the base word order. However, the exact opposite pattern is attested in the data of some children. The emergence of the base word order prior to the derived word order, even though the base word order is not grammatical in adult Hebrew, indicates that input is not the only factor determining the emergence pattern of possessives; in fact, these data indicate that the availability of the syntactic structure in the children's grammar is more important than input frequency.

\section{Individual variation}


The data presented in Section 3 have shown a large individual variation in the acquisition of possessives. This was evident in the acquisition of inflectional morphemes, possessive pronouns, prepositions, and the word order of the possessive construction. In addition, there was also individual variation in the emergence of possessive pronouns vs. inflectional morphemes. For example, data from English have shown that some children start using possessive pronouns before the use of possessive $-s$, whereas others start using possessive pronouns after consistent use of $-s$.

Most of the studies presented in this paper included naturalistic data of a very small number of children using a longitudinal design. As a result, it is unclear whether or not the individual variation observed reflects differences between the studies in the recording intervals and contexts or whether there are different developmental paths in the acquisition possessives. Future research is necessary to address the issue of individual variation.

\section{Future research}

Although the acquisition of possessives has been investigated for many decades, there are still large gaps in our knowledge about how possessives are acquired. One of the reasons for this is that they are acquired very early and it is very difficult to use elicitation tasks with 2-and 3-yearold children. As a result, our knowledge on the acquisition of possessives is based mainly on naturalistic longitudinal and diary data. Longitudinal data are very good in addressing developmental aspects of language, but they also have important limitations. Most of the times, they consist of case studies or case study series. This limits the generalizability of the findings, especially when there is large individual variation between children. Moreover, lack of particular structures in the children's language cannot provide evidence that a structure has not been 
acquired; it may reflect the lack of obligatory contexts for the particular construction. For example, if a language allows two word orders for possessives, but children use only one, this does not mean that they cannot use the other one. Similarly, if children use prepositional possessives, but not non-prepositional ones, this does not provide evidence that they have not acquired both. Structures that are rare in the input, like recursive possessives may not be found in the datasets because there were no obligatory contexts. Finally, there may be gaps in the developmental stages of structures that are acquired in a short period of time if there are long intervals between the recordings. What is the way forward for the research into the acquisition of possessives?

There are at least three ways to capture the acquisition of possessives more accurately: 1) through comprehension experiments that are appropriate for very young children; 2) through dense longitudinal data; 3 ) through elicitation experiments for rare constructions. In the remaining of this section I will discuss how these three methods could fill the gap in the acquisition of possessives.

\section{Comprehension/perception experiments}

Recent research has used comprehension/perception experiments to address whether or not infants are sensitive to the use of grammatical morphemes using the head turn or the preferential looking paradigm (e.g., Golinkoff, Hirsh-Pasek, \& Schweisguth, 2001; Höhle \& Weissenborn, 2003). Experiments using the head turn paradigm involve infants/young children listening to sentences, for example, with and without particular grammatical morphemes and measuring how long they turn their head towards the direction of the sentences with and without the grammatical morphemes. Experiments using the preferential looking paradigm involve also children listening 
to sentences, but this time, pictures appear on a computer screen and the task measures how long children look at the pictures. Such tasks can be used with very young children when they are not yet producing possessives or when they show variable use of possessives. They can reveal whether or not children are sensitive to the use of possessives and whether they can comprehend them. Such tasks involve group data. Therefore, the data are more representative of the population and allow generalizations.

\section{Using dense longitudinal data}

When a particular structure is acquired in a relatively fast pace, the length of intervals between the recordings is crucial. If the intervals are long, some developmental stages may be missed out. The data presented in Section 3 come from studies using longitudinal data with varying sampling intervals. This makes it very difficult to compare findings from different studies and also compare the development of possessives across languages. In recent years, several datasets of dense data have been created and researchers have started using them to address language acquisition (e.g., Maslen, Theakston, Lieven, \& Tomasello, 2004; see also Demuth, 2008; Lieven \& Behrens, 2012). Previous studies have shown that some aspects of the possessives are acquired very early and very rapidly (e.g., Tomasello, 1998). Therefore, dense longitudinal datasets would be ideal to investigate in depth the early acquisition of possessives.

\section{Elicitation and comprehension experiments for rare constructions}

Elicitation tasks and comprehension experiments can be used for constructions that are late acquired and are rare in the input, such as recursive possessives. There is already some recent research on the acquisition of recursive possessives in English using elicitation and 
comprehension tasks with children after the age of three (Limbach \& Adone, 2010; PérezLeroux, Castilla-Earls, Bejar, \& Massam, in press), but the number of children in these studies is relatively small and even 5-year-old children are not performing at ceiling. Research with a larger sample of children across a wider age range can reveal when recursive possessives are acquired. In addition, research in other languages that allow recursive possessives, such as Greek, can reveal whether or not late acquisition of recursive possessives holds across languages. 


\section{References}

Abney, S. (1987). The English noun phrase in its sentential aspect. MIT, .

Adger, D. (2003). Core syntax: a minimalist approach. Oxford: Oxford University Press.

Alexiadou, Artemis (2001) Functional structure in nominals: nominalization, and ergativity. Amsterdam: John Benjamins.

Armon-Lotem, S. (1998). Mommy sock in a minimalist eye: on the acquisition of DP in Hebrew. In N. Dittmar \& Z. Penner (Eds.), Issues in the theory of language acquisition: essays in Honor of Jürgen Weissenborn (pp. 15-36). Bern: Peter Lang.

Armstrong, T. (2001). Research report. Amherst: University of Massachusetts.

Baron, I., Herslund, M., \& Sørensen, F. (Eds.). (2001). Dimensions of Possession. Amsterdam/Philadelphia: Benjamins.

Berman, R. A. (1985). The acquisition of Hebrew. In D. I. Slobin (Ed.), The crosslinguistic study of language acquisition (Vol. 1 ). Hillsdale, NJ: Erlbaum.

Berman, R. A. (1987). A developmental route: Learning about the form and use of complex nominals in Hebrew. Linguistics, 25-6, 1057-1085.

Bloom, L. (1970). Language Development: Form and function in emerging grammars. Cambridge, MA: MIT Press.

Borer, H. (1999). Deconstructing the construct. In K. Johnson \& I. G. Roberts (Eds.), Beyond Principles and Parameters (pp. 43-89). Dordrecht: Kluwer.

Bowerman, M. F. (1973). Early Syntactic Development: A Crosslinguistic Study with Special Reference to Finnish. London: Cambridge University Press.

Brown, R., \& Bellugi, U. (1964). Three Processes in the Child's Acquisition of Syntax. Harvard Educational Review, 34,(2,), 133-151. 
Christofidou, A. (1998). Number or Case first? Evidence from Modern Greek. In A. Aksu-Koç, E. Erguvanli Taylan, A. Sumru Özsoy \& A. Küntay (Eds.), Perspectives on Language Acquisition. Selected papers from the VIIth International Congress for the study of Child Language (pp. 46-59).

Clancy, P. M. (1985). The acquisition of Japanese. In D. I. Slobin (Ed.), The crosslinguistic study of language acquisition (Vol. 1). Hillsdale, NJ: Erlbaum.

de Villiers, J. G., \& de Villiers, P. A. (1973). A crosssectional study of the acquisition of grammatical morphemes. Journal of Psycholinguistic Research, 2, 267-278.

Demuth. K. (2008). Exploiting corpora for language acquisition research. In H. Behrens (Ed.), Corpora in language acquisition research : history, methods, perspectives, (pp.199-205). Amsterdam : John Benjamins.

Eisenbeiß, S. (2000). The Acquisition of the DP in German Child Language. In M.-A. Friedemann \& L. Rizzi (Eds.), Acquisition of Syntax. Issues in Comparative Developmental Linguistics (pp. 26-63). Longman.

Eisenbeiß, S., Matsuo, A., \& Sonnenstuhl, I. (2009). Learning to Encode Possession. In W. McGregor (Ed.), The Expression of Possession (pp. 143-211). Berlin: deGruyter.

Gerken, L. A. (1996). Prosodic structure in young children's language production. Language, 72, 683-712.

Golinkoff, R., Hirsh-Pasek, K., \& Schweisguth, M. A. (2001). A reappraisal of young children's knowledge of grammatical morphemes. In J. Weissenborn \& B. Höhle (Eds.), Approaches to bootstrapping: phonological, lexical, syntactic, and neurophysiological aspects of early language acquisition (Vol. 1, pp. 167-188). Amsterdam: Benjamins. 
Höhle, B. \& Weissenborn, J. (2003) German-learning infants' ability to detect unstressed closedclass elements in continuous speech. Developmental Science, 6, 154-159.

Lieven, E. V. M., \& Behrens, H. (2012). Dense sampling. In E. Hoff (Ed.), Research methods in child language: a practical guide (pp. 226-239). Oxford: Blackwell.

Limbach, M. \& Adone, D. (2010). Language acquisition of recursive possessives in English. In K. Franich, K. M. Iserman \& L. L. Keil (Eds.), Proceedings of the 34 Boston University Conference on Language Development (pp. 281-290). Somerville, MA: Cascadilla Press.

MacWhinney, B., \& Snow, C. (1990). The child language data exchange system: An update. Journal of Child Language, 17, 457-472.

Marinis, T. (2000). The acquisition of the DP in Modern Greek. Unpublished PhD thesis, University of Potsdam.

Marinis, T. (2002). Acquiring the Possessive Construction in Modern Greek. In I. Lasser (Ed.), The Process of Language Acquisition (pp. 57-80). Frankfurt/Berlin: Peter Lang.

Marinis, T. (2003). The Acquisition of the DP in Modern Greek (Vol. 31). Amsterdam: John Benjamins.

Maslen, R. J. C., Theakston, A. L., Lieven, E. V. M., \& Tomasello, M. (2004). A Dense Corpus Study of Past Tense and Plural Overregularization in English. Journal of Speech, Language, and Hearing Research, 47, 1319-1333.

Mills, A. E. (1985). The acquisition of German. In D. I. Slobin (Ed.), The crosslinguistic study of language acquisition (Vol. 1 ). Hillsdale, NJ Lawrence Erlbaum Associates.

Penner, Z., \& Weissenborn, J. (1996). Strong continuity, parameter setting and the trigger hierarchy: On the acquisition of the DP in Bernese Swiss German and high German. In H. Clahsen (Ed.), Generative perspectives on language acquisition: Empirical findings, 
theoretical considerations and crosslinguistic comparisons (pp. 161-200). Amsterdam: Benjamins.

Pérez-Leroux, A. T. , Castilla-Earls, A., Bejar, S., \& Massam, D. (in press). Elmo's sister's ball: The problem of acquiring nominal recursion. Language Acquisition.

Prince, A. \& Smolensky, P. (2004). Optimality Theory:constraint interaction in generative grammar. Oxford, Blackwell.

Radford, A. (1990). Syntactic theory and the acquisition of English syntax. Oxford: Blackwell.

Radford, A., \& Galasso, J. (1998). Children's possessive structures: a case study. Essex research reports in linguistics, 19, 37-45.

Ritter, E. (1991). Two Functional Categories in Noun Phrases: Evidence from Modern Hebrew. In S. Rothstein (Ed.), Perspectives on Phrase Structure: Heads and Licensing (pp. 3762). New York: Academic Press.

Roeper, T. (2007). The prism of language: how child language illuminates humanism. Cambridge, Massachusetts: MIT Press.

Roeper, T., \& Snyder, W. (2005). Language learnability and the forms of recursion. In A. M. Di Sciullo \& R. Delmonte (Eds.), UG and External Systems: Language, Brain and Computation (pp. 155-169). Amsterdam: John Benjamins.

Siloni, T. (1996). Hebrew Noun Phrases: Generalized Noun Raising. In A. Belletti \& L. Rizzi (Eds.), Parameters and functional heads. Essays in Comparative Syntax (pp. 239-267). Oxford: Oxford University Press.

Stephany, U. (1995). The acquisition of Greek. In D. I. Slobin (Ed.), The crosslinguistic study of language acquisition. Vol. 4. Hillsdale, NJ: Lawrence Erlbaum. 
Stern, C., \& Stern, W. (1907). Die Kindersprache: Eine psychologische und sprachtheoretische Untersuchung. Leipzig: Barth.

Tomasello, M. (1998). One child's early talk about possession. In R. J. Newman (Ed.), The linguistics of giving (pp. 349-373). Philadelphia John Benjamins.

Tomasello, M. (2003). Constructing a Language: a usage-based theory of language acquisition. Harvard University Press.

Young, V. (2002). Knowledge and learning in natural language. New York: Oxford University Press. 